\title{
Genetic diversity of Gracilaria changii (Gracilariaceae, Rhodophyta) from west coast, Peninsular Malaysia based on mitochondrial cox1 gene analysis
}

\author{
Yoon-Yen Yow $•$ Phaik-Eem Lim • Siew-Moi Phang
}

Received: 6 February 2010/Revised and accepted: 12 May 2010/Published online: 10 June 2010

(C) Springer Science+Business Media B.V. 2010

\begin{abstract}
Mitochondrial cytochrome $c$ oxidase subunit I (cox1) was employed to investigate the intraspecific genetic diversity of Gracilaria changii collected from various localities distributed along the west coast of Peninsular Malaysia. Gracilaria changii is an agarophyte with potential for commercialization in Malaysia as it has high yields of good quality agar with high gel strength for the production of food grade agar and agarose. The phylogeographic aspect of $G$. changii has not been studied despite its abundance and potential commercialization. In this study, six mitochondrial haplotypes $(\mathrm{C} 1-\mathrm{C} 6)$ were revealed from 62 specimens varying by $0-3$ bp over 923 bp. Results indicate that haplotype $\mathrm{C} 1$ is the common ancestor and the most widespread haplotype due to its prevalence in Morib, Gua Tanah, Middle Banks, Batu Besar, Batu Tengah, Sungai Pulai, and Kuala Sungai Merbok. In this study, Morib was suggested as contributing the highest intrapopulation diversity with the identification of three haplotypes. The mitochondrial marker cox 1 is a highly divergent mitochondrial marker and is applicable for studies on species identification and assessment of genetic diversity of $G$. changii.
\end{abstract}

Keywords cox 1 gene - Gracilaria changii .

Phylogeography $\cdot$ Genetic diversity

Paper presented at the 7th Asia Pacific Congress on Algal Biotechnology, New Delhi, 2009.

Y.-Y. Yow $\cdot$ P.-E. Lim $\cdot$ S.-M. Phang

Institute of Ocean and Earth Sciences, University of Malaya,

50603 Kuala Lumpur, Malaysia

Y.-Y. Yow $\cdot$ P.-E. Lim $(\bowtie) \cdot$ S.-M. Phang

Institute of Biological Sciences, University of Malaya,

50603 Kuala Lumpur, Malaysia

e-mail: phaikeem@um.edu.my

\section{Introduction}

Gracilaria is the second largest genus of the red algae (Brodie and Zuccarello 2007) comprising more than 150 species distributed worldwide (Byrne et al. 2002), many of which are of economic (Oliveira et al. 2000) and ecological importance (McLachlan and Bird 1986). A total of 20 species of Gracilaria have been recorded for Malaysia (Lim and Phang 2004).

Gracilaria changii from Malaysia was originally described by Xia and Abbott (1987) and is widely distributed in the mangrove areas fringing the west coast of Peninsular Malaysia (Phang et al. 1996; Lim and Phang 2004). The wide use of high-quality agar and agarose with good gel strength extracted from $G$. changii (Phang et al. 1996) has generated an increased interest among scientists and entrepreneurs, e.g., substitution for gelatin in food, cosmetic, and pharmaceutical applications. G. changii contains a notable amount of protein, fatty acids (Chu et al. 2003), and bioactive compounds (Wong et al. 2006). However, no information about the intraspecific genetic diversity of this species is available. The high demand for G. changii in agar production has increased dramatically and resulted in the overharvesting of wild populations. Losses in seaweeds are also attributed to human activities through habitat destruction, overharvesting, pollution, development of coastal areas for tourism, global climate change, and introduction of alien species. Buschmann et al. (2001) reported that there was a major shift in the algal industry in the 1980 s to obtaining raw material from harvesting natural beds to predominantly mariculturebased production as a result of decline in wild populations due to overexploitation. Expansion of mariculture also led to introductions of marine algae from one geographic region to another, which has been documented by a 
number of researchers (McIvor et al. 2001; Nelson et al. 1996; Uwai et al. 2006a).

Genetic diversity is the fundamental component of biodiversity that quantifies the magnitude of genetic variability within a population. Measurement of genetic diversity contributes important clues to an understanding of the nature of forces acting on genetic variation, pattern, level of genetic variation, and evolutionary history. Genetic diversity within a population also has ecological effects on productivity, growth, and sustainability, as well as interspecific interactions within communities and ecosystem-level processes (Hughes et al. 2008).

DNA-based molecular markers provide a pivotal role in the assessment of genetic diversity for a highly plastic genus such as Gracilaria (Bird and McLachlan 1982). Application of mitochondrial DNA in animal population studies and phylogenetic reconstruction has increased owing to the rapid evolution, lack of recombination, and uniparental inheritance of mtDNA (Avise 1994). The success of mitochondrial marker cytochrome oxidase subunit I (coxl) in animals led to the assessment of this marker for applications in DNA bar coding in red algae (Saunders 2005).

A number of intraspecific markers have been employed on phylogenetic and genetic diversity studies such as the cox 1 gene, (Robba et al. 2006; Yang et al. 2007; Sherwood 2008), mitochondrial cytochrome oxidase subunit 3, cox3 (Steel et al. 2000; Coyer et al. 2004; Uwai et al. 2006b), the mitochondrial-encoded cox2-3 spacer (Zuccarello et al. 1999; Zuccarello and West 2002; Rueness 2005; Zuccarello et al. 2006b; Vidal 2008), nuclear-encoded internal transcribed spacers of the ribosomal cistrons, ITS1 and ITS2 (Bellorin et al. 2002; Marston and Villalard-Bohnsack 2002; Cho et al. 2007), the plastid-encoded RuBisCo spacer (Byrne et al. 2002; Zuccarello et al. 2006a), and $r b c \mathrm{~L}$ gene (Nam et al. 2000; McIvor et al. 2001; Gurgel and Fredericq 2004). The first study on the haplotype analysis of the cox 1 coding gene of Gracilaria vermiculophylla by Yang et al. (2007) showed it to be a reliable molecular marker for intraspecific study and useful for revealing species relationships, population structure, and the hidden diversity of red algae.

The present study aims to infer the geographic distribution of G. changii along the west coast of Peninsular Malaysia. Our work on comparing the suitability of the $\operatorname{cox} 1$ and the $\operatorname{cox} 2-3$ spacer for genetic diversity of $G$. changii showed that the $\operatorname{cox} 1$ gene was better than the cox 2-3 spacer, giving higher resolution (unpublished data). Hence, in this study, the mitochondrial cytochrome $c$ oxidase subunit I $(\operatorname{cox} 1)$ gene was used, although the uniparental inheritance and limited variation of markers have been a handicap for certain circumstances. We have focused primarily on samples collected from the west coast of Peninsular Malaysia. However, from this study, we could not estimate the vectors, factors, and stresses that may have contributed to the existence of the various haplotypes shown in G. changii as details on the shipping, environmental changes, and introduction of alien marine algae into this region are not available.

\section{Materials and methods}

Healthy samples of Gracilaria changii (Xia et Abbott) Abbott, Zhang et Xia were collected randomly in the field from various localities distributed along the west coast of Peninsular Malaysia: Penang, Kedah, Selangor, Negeri Sembilan, Malacca, and Johore. Specimens examined in the present study are listed in Table 1 . The specimens were cleaned with seawater and distilled water. Mud or dirt, epiphytes, epizoites, and fungi were removed by successive washing in seawater with a final rinse in distilled water. Specimens were dried in silica gel prior to isolation of their DNA.

Genomic DNA was extracted from approximately $10 \mathrm{mg}$ of tips from dried specimens of G. changii (ground into powder using liquid nitrogen) with DNeasy Plant Mini Kit (Qiagen, Germany). All the isolation steps were carried out according to the instructions of the manufacturer with minor modification by incubating the disrupted samples with buffer AP1 for $20 \mathrm{~min}$ at $65^{\circ} \mathrm{C}$.

The amplifications of extracted genomic DNA and DNA sequencing were carried out using mitochondrial primers of $\operatorname{cox} 143 \mathrm{~F}$ and $\cos 11549 \mathrm{R}$ from Geraldino et al. (2006). The amplification of DNA was performed in a final volume of $25 \mu \mathrm{L}$ containing $2.5 \mu \mathrm{L} 10 \times$ buffer, $0.2 \mathrm{mM}$ of each dNTP (dATP, dTTP, dCTP, and dGTP), 10 pmol of each forward and reverse primer, $1.5 \mathrm{U}$ Taq polymerase, and $20-50 \mathrm{ng}$ of genomic DNA. Ultrahigh-quality water was added to make up the final total volume of $25 \mu \mathrm{L}$. polymerase chain reaction (PCR) was carried out by GeneAmp ${ }^{\circledR}$ PCR system 2700 (Applied Biosystem) thermal cycle with an initial denaturation at $94^{\circ} \mathrm{C}$ for $10 \mathrm{~min}$ to denature the doublestranded DNA, followed by 35 cycles of amplification (denaturing at $94^{\circ} \mathrm{C}$ for $30 \mathrm{~s}$, annealing at $50^{\circ} \mathrm{C}$ for $30 \mathrm{~s}$, and extension at $72^{\circ} \mathrm{C}$ for $2 \mathrm{~min}$ ) with a final extension for $10 \mathrm{~min}$ at $72^{\circ} \mathrm{C}$. The amplified products were electrophoresed on $1 \%(w / v)$ TAE agarose gel pre-stained with ethidium bromide. PCR products were purified with the QIaquick PCR Purification Kit (Qiagen).

Sequencing data were analyzed and edited using Chromas 2.01 (Technelysium Pty Ltd., Australia) and BioEdit 7.0.9.0 (Hall 1999) software. Edited sequences were aligned by CLUSTAL X program (Thompson et al. 1997) followed by PAUP 4.0b10 (Swofford 2002). Haplotype networks (gene genealogies) were created using TCS 1.13 (Clement et al. 2000) to calculate the minimum 
Table 1 Sampling location and haplotype identified for G. changii by cox 1 gene

\begin{tabular}{|c|c|c|c|c|}
\hline Collection site & Number of specimens & Collection number of specimen & Gene bank accession number & Haplotype \\
\hline \multirow[t]{7}{*}{ Kuala Sungai Merbok, Kedah } & \multirow[t]{7}{*}{7} & PSM11101_UMSS 0001 & GU645726 & $\mathrm{C} 1$ \\
\hline & & PSM11102_UMSS 0002 & GU645727 & $\mathrm{C} 1$ \\
\hline & & PSM11103_UMSS 0003 & GU645728 & $\mathrm{C} 1$ \\
\hline & & PSM11104_UMSS 0004 & GU645764 & $\mathrm{C} 1$ \\
\hline & & PSM11105_UMSS 0005 & GU645765 & $\mathrm{C} 1$ \\
\hline & & PSM11106_UMSS 0006 & GU645729 & $\mathrm{C} 1$ \\
\hline & & PSM11107_UMSS 0007 & GU645730 & $\mathrm{C} 1$ \\
\hline \multirow[t]{11}{*}{ Middle Banks, Penang } & \multirow[t]{11}{*}{11} & PSM11108_UMSS 0008 & GU645731 & $\mathrm{C} 1$ \\
\hline & & PSM11109_UMSS 0009 & GU645732 & $\mathrm{C} 1$ \\
\hline & & PSM11110_UMSS 0010 & GU645766 & $\mathrm{C} 1$ \\
\hline & & PSM11111_UMSS 0011 & GU645733 & $\mathrm{C} 1$ \\
\hline & & PSM11112_UMSS 0012 & GU645734 & $\mathrm{C} 1$ \\
\hline & & PSM11113_UMSS 0013 & GU645735 & $\mathrm{C} 1$ \\
\hline & & PSM11114_UMSS 0014 & GU645736 & $\mathrm{C} 1$ \\
\hline & & PSM11115_UMSS 0015 & GU645737 & $\mathrm{C} 1$ \\
\hline & & PSM11116_UMSS 0016 & GU645767 & $\mathrm{C} 1$ \\
\hline & & PSM11117_UMSS 0017 & GU645768 & $\mathrm{C} 1$ \\
\hline & & PSM11118_UMSS 0018 & GU645738 & $\mathrm{C} 1$ \\
\hline \multirow[t]{10}{*}{ Morib, Selangor } & \multirow[t]{10}{*}{10} & PSM11119_UMSS 0019 & GU645769 & $\mathrm{C} 1$ \\
\hline & & PSM11120_UMSS 0020 & GU645739 & $\mathrm{C} 5$ \\
\hline & & PSM11121_UMSS 0021 & GU645740 & $\mathrm{C} 5$ \\
\hline & & PSM11122_UMSS 0022 & GU645770 & $\mathrm{C} 4$ \\
\hline & & PSM11123_UMSS 0023 & GU645741 & $\mathrm{C} 5$ \\
\hline & & PSM11124_UMSS 0024 & GU645742 & $\mathrm{C} 5$ \\
\hline & & PSM11125_UMSS 0025 & GU645771 & $\mathrm{C} 5$ \\
\hline & & PSM11126_UMSS 0026 & GU645743 & $\mathrm{C} 5$ \\
\hline & & PSM11127_UMSS 0027 & GU645772 & $\mathrm{C} 5$ \\
\hline & & PSM11128_UMSS 0028 & GU645744 & $\mathrm{C} 5$ \\
\hline \multirow[t]{9}{*}{ Gua Tanah, Malacca } & \multirow[t]{9}{*}{9} & PSM11129_UMSS 0029 & GU645773 & $\mathrm{C} 1$ \\
\hline & & PSM11130_UMSS 0030 & GU645745 & $\mathrm{C} 1$ \\
\hline & & PSM11131_UMSS 0031 & GU645774 & $\mathrm{C} 1$ \\
\hline & & PSM11132_UMSS 0032 & GU645746 & $\mathrm{C} 1$ \\
\hline & & PSM11133_UMSS 0033 & GU645747 & $\mathrm{C} 1$ \\
\hline & & PSM11134_UMSS 0034 & GU645748 & $\mathrm{C} 1$ \\
\hline & & PSM11135_UMSS 0035 & GU645749 & $\mathrm{C} 1$ \\
\hline & & PSM11136_UMSS 0036 & GU645750 & $\mathrm{C} 1$ \\
\hline & & PSM11137_UMSS 0037 & GU645751 & $\mathrm{C} 1$ \\
\hline \multirow[t]{8}{*}{ Batu Besar, Malacca } & \multirow[t]{8}{*}{8} & PSM11138_UMSS 0038 & GU645775 & $\mathrm{C} 1$ \\
\hline & & PSM11139_UMSS 0039 & GU645776 & $\mathrm{C} 1$ \\
\hline & & PSM11140_UMSS 0040 & GU645777 & $\mathrm{C} 2$ \\
\hline & & PSM11141_UMSS 0041 & GU645778 & $\mathrm{C} 1$ \\
\hline & & PSM11142_UMSS 0042 & GU645752 & $\mathrm{C} 1$ \\
\hline & & PSM11143_UMSS 0043 & GU645753 & $\mathrm{C} 1$ \\
\hline & & PSM11144_UMSS 0044 & GU645754 & $\mathrm{C} 1$ \\
\hline & & PSM11145_UMSS 0045 & GU645755 & $\mathrm{C} 1$ \\
\hline \multirow[t]{4}{*}{ Batu Tengah, Malacca } & \multirow[t]{4}{*}{7} & PSM11146_UMSS 0046 & GU645756 & $\mathrm{C} 1$ \\
\hline & & PSM11147_UMSS 0047 & GU645779 & $\mathrm{C} 1$ \\
\hline & & PSM11148_UMSS 0048 & GU645780 & $\mathrm{C} 1$ \\
\hline & & PSM11149_UMSS 0049 & GU645781 & $\mathrm{C} 1$ \\
\hline
\end{tabular}


Table 1 (continued)

\begin{tabular}{|c|c|c|c|c|}
\hline Collection site & Number of specimens & Collection number of specimen & Gene bank accession number & Haplotype \\
\hline & & PSM11150_UMSS 0050 & GU645757 & $\mathrm{C} 1$ \\
\hline & & PSM11151_UMSS 0051 & GU645758 & $\mathrm{C} 1$ \\
\hline & & PSM11152_UMSS 0052 & GU645759 & $\mathrm{C} 1$ \\
\hline \multirow[t]{6}{*}{ Sungai Pulai, Johore } & 6 & PSM11153_UMSS 0053 & GU645782 & $\mathrm{C} 1$ \\
\hline & & PSM11154_UMSS 0054 & GU645783 & $\mathrm{C} 1$ \\
\hline & & PSM11155_UMSS 0055 & GU645784 & $\mathrm{C} 1$ \\
\hline & & PSM11156_UMSS 0056 & GU645785 & $\mathrm{C} 1$ \\
\hline & & PSM11157_UMSS 0057 & GU645760 & $\mathrm{C} 1$ \\
\hline & & PSM11158_UMSS 0058 & GU645761 & $\mathrm{C} 1$ \\
\hline \multirow[t]{4}{*}{ Teluk Pelanduk, Negeri Sembilan } & 4 & PSM11159_UMSS 0059 & GU645786 & C6 \\
\hline & & PSM11160_UMSS 0060 & GU645762 & C6 \\
\hline & & PSM11161_UMSS 0061 & GU645787 & C6 \\
\hline & & PSM11162_UMSS 0062 & GU645763 & $\mathrm{C} 3$ \\
\hline
\end{tabular}

number of mutational steps by which the sequences can be joined with $>95 \%$ confidence.

\section{Results}

Sixty-two specimens of $G$. changii from eight different biogeographic locations (i.e., Morib, Gua Tanah, Middle Banks, Batu Besar, Batu Tengah, Sungai Pulai, Kuala Sungai Merbok, and Teluk Pelanduk) were used for the study of genetic diversity using the $\operatorname{cox} 1$ gene.

A statistical parsimony network of 62 taxa aligned as 923 characters of the cox 1 gene revealed six haplotypes based on the specimens collected from the eight localities along the west coast of Peninsular Malaysia, namely, $\mathrm{C}$, C2, C3, C4, C5, and C6 (Fig. 1 and Table 2). Among the examined populations, prevailing haplotype $\mathrm{C} 1$ was inferred as the basal haplotype. Haplotype $\mathrm{C} 1$ was found in Kuala Sungai Merbok, Middle Banks, Morib, Gua Tanah, Batu Besar, Batu Tengah, and Sungai Pulai. Haplotype C2 was detected in Batu Besar and differs from $\mathrm{C} 1$ by three mutation changes: an adenine to cytosine at position 172, a thymine to cytosine at position 410 , and an adenine to guanidine at position 728. Haplotype C3 from Teluk Pelanduk was formed from the ancestral $\mathrm{C} 1$ with two base changes where an adenine was substituted by cytosine at position 25 and followed by substitution of cytosine to thymine at position 108. There was a substitution of an adenine to guanidine at position 644 for $\mathrm{C} 4$; this haplotype was contributed by the Morib samples. The deletions of thymine at position 16 and an adenine at position 43 with a mutation change of adenine to guanidine at site 644 were found for haplotype C5 from Morib. An insertion of cytosine at site 40 was observed from Teluk Pelanduk and differentiated haplotype C6.

\section{Discussion}

The cox 1 gene has been reported as an ideal marker for DNA bar coding of red algae by several researchers (e.g., Saunders 2005; Geraldino et al. 2006; Robba et al. 2006). In addition, it is also useful for revealing the population structure and the hidden diversity of red algae (Robba et al. 2006). The specimens of $G$. changii collected from different biogeographical locations along the west coast of Peninsular Malaysia were used to elucidate the distribution of genetic diversity using the cox 1 gene; their genetic distribution is shown in Fig. 2.

Based on the results of TCS software, haplotype C1 was clarified as the common ancestor and the most widespread

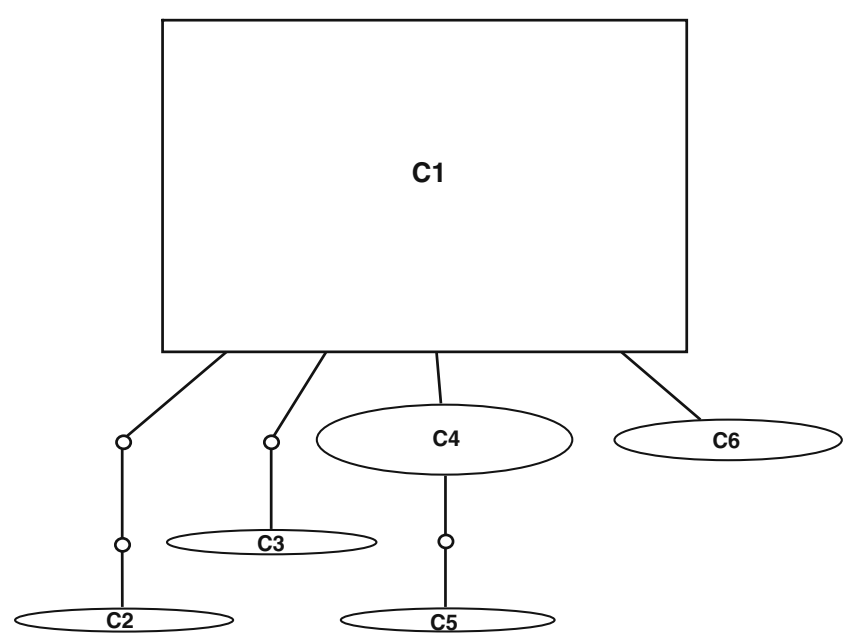

Fig. 1 Statistical parsimony networks for cox 1 haplotypes of $G$. changii. Lines represent parsimonious connections between haplotypes with a probability higher than $95 \%$, with each representing one mutational step, and the small circles indicate missing haplotype. The size of square or oval corresponds to the haplotype frequency. Haplotype $\mathrm{C} 1$ was inferred as the hypothetical ancestral haplotype 
Table 2 Variation site in DNA sequences of $G$. changii for mitochondrial haplotype from various localities

\begin{tabular}{|c|c|c|c|c|c|c|c|c|c|c|}
\hline \multirow[t]{2}{*}{ Haplotype } & \multirow[t]{2}{*}{ Collection site $^{a}$} & \multicolumn{9}{|c|}{ Variation sites in DNA sequence } \\
\hline & & 16 & 25 & 40 & 43 & 108 & 172 & 410 & 644 & 728 \\
\hline \multirow[t]{6}{*}{$\mathrm{C} 1$} & $\begin{array}{l}\text { Kuala Sungai Merbok (100\%) } \\
\text { Middle Banks (100\%) }\end{array}$ & $\mathrm{T}$ & A & & A & $\mathrm{C}$ & A & $\mathrm{T}$ & A & A \\
\hline & Morib (10\%) & & & & & & & & & \\
\hline & Gua Tanah $(100 \%)$ & & & & & & & & & \\
\hline & Batu Besar (87\%) & & & & & & & & & \\
\hline & Batu Tengah (100\%) & & & & & & & & & \\
\hline & Sungai Pulai $(100 \%)$ & & & & & & & & & \\
\hline $\mathrm{C} 2$ & Batu Besar (13\%) & $\mathrm{T}$ & A & & A & $\mathrm{C}$ & $\mathrm{C}$ & $\mathrm{C}$ & A & G \\
\hline $\mathrm{C} 3$ & Teluk Pelanduk (25\%) & $\mathrm{T}$ & $\mathrm{C}$ & & A & $\mathrm{T}$ & A & $\mathrm{T}$ & A & A \\
\hline $\mathrm{C} 4$ & Morib $(80 \%)$ & $\mathrm{T}$ & $\mathrm{A}$ & & A & $\mathrm{C}$ & A & $\mathrm{T}$ & $\mathrm{G}$ & A \\
\hline $\mathrm{C} 5$ & Morib $(10 \%)$ & & $\mathrm{A}$ & & & $\mathrm{C}$ & A & $\mathrm{T}$ & $\mathrm{G}$ & A \\
\hline C6 & Teluk Pelanduk (75\%) & $\mathrm{T}$ & A & $\mathrm{C}$ & $\mathrm{A}$ & $\mathrm{C}$ & $\mathrm{A}$ & $\mathrm{T}$ & $\mathrm{A}$ & $\mathrm{A}$ \\
\hline
\end{tabular}

haplotype for $G$. changii due to its prevalence in Kuala Sungai Merbok, Middle Banks, Morib, Gua Tanah, Batu Besar, Batu Tengah, and Sungai Pulai. G. changii in Morib, Selangor, provided the largest divergence with the identi- fication of three haplotypes (i.e., C1, C4, and C5). Based on the distribution of the haplotype along the coastline of Malacca, two haplotypes were found from Batu Besar. Haplotype $\mathrm{C} 1$ and $\mathrm{C} 2$ differed from each other by three

A) Kuala Sungai Merbok, Kedah (7)

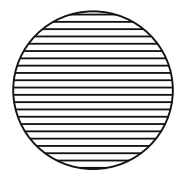

B) Middle Banks (11)

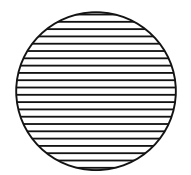

C) Morib, Selangor (10)
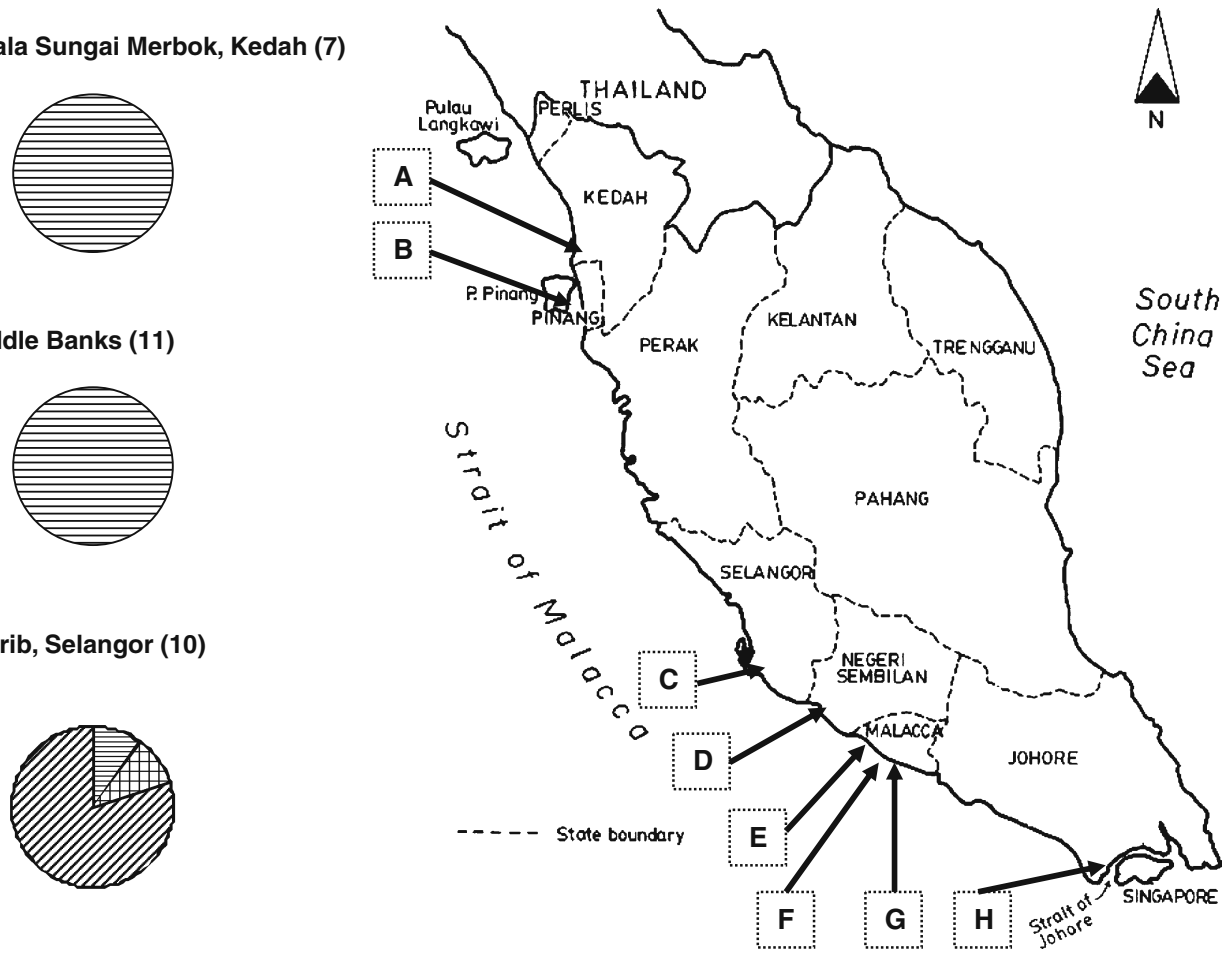

D) Teluk Pelanduk, Negeri Sembilan (4)

E) Gua Tanah, Malacca (9)

F) Batu Besar, Malacca (8)
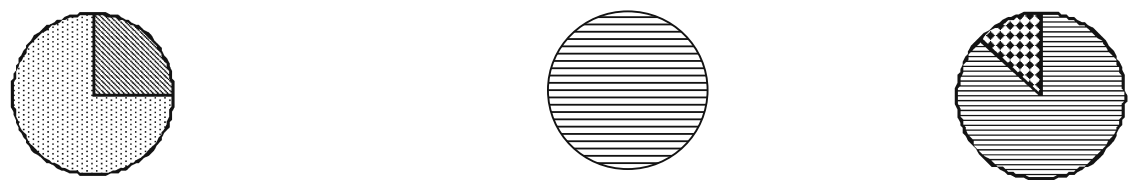

H) Sungai Pulai, Johore (6)

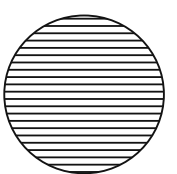

G) Batu Tengah, Malacca (7)

Fig. 2 Haplotype distribution (C1-C6) of cox1 for G. changii along the west coast of Peninsular Malaysia. The number of examined samples is shown in parentheses (map of west coast Peninsular

Malaysia adapted from http://www.fao.org/docrep/field/009/ag160e/ AG160E09.htm) 
substitutions. Two haplotypes (C3 and C6) were discovered in Teluk Pelanduk with the absence of the common ancestor (C1). The samples from Kuala Sungai Merbok, Middle Banks, Gua Tanah, Batu Tengah, and Sungai Pulai exhibited the lowest genetic diversity of $G$. changii since only the basal haplotype $(\mathrm{C} 1)$ was observed. Intraspecific nucleotide differences ranged from $0-3$ bp $(0.33 \%)$ over 923 bp. According to Saunders (2005), intraspecific nucleotide differences for red algae range from 0 to $2 \mathrm{bp}$, and interspecific nucleotide differences were more than $30 \mathrm{bp}$; our study showed similar results. The type species of G. changii was described for the first time from Middle Banks, Penang (Phang 1994). The study indicated that Morib may be the original locality of $G$. changii as the highest level of genetic variation was observed there; however, the origin of $G$. changii can only be verified with additional sampling from wider biogeographical areas and an increased number of individuals (a minimum of ten) for each locality examined.

The Malacca Straits is the world's second busiest commercial shipping lane and has been threatened by man's activities of shipping traffic, land reclamation, and fishing since the 1980s. Phang (1998) reported that the sheltered coastline of the west coast of Peninsular Malaysia was dominated by mangrove swamps with water temperature ranging from $23^{\circ} \mathrm{C}$ to $31^{\circ} \mathrm{C}$, salinity from 28 to $34 \mathrm{ppt}$, and semi-diurnal tides. Mangrove areas of Morib are dominated by G. changii, G. edulis, and G. salicornia. Morib beach is well known as a tourist destination and is also surrounded by factories and poultry farms. Waste and discharge from these activities contributes to coastal pollution. G. changii and other species in this region may have had to adapt to these stressed environments. G. changii is capable of adapting to the harsh silted mangrove and polluted areas (Phang et al. 1996). We suggest that haplotype $\mathrm{C} 1$ is the common ancestor of $G$. changii and evolved over time into the various haplotypes, namely, C2, C3, C4, C5, and C6, in order to cope with environmental changes and as a consequence of geographic distribution along the coastal regions of the west coast of Peninsular Malaysia. Further study will be required to determine whether the various cox 1 haplotypes correlate with ecotypes that differ in their response to the environment.

Seaweeds are distributed around the world by various processes. More than 100 seaweed species have been documented that are widely dispersed across their native ranges due to anthropogenic activities (Farnham et al. 1973; Rueness 1989; Curiel et al. 1998; Fletcher and Farrell 1999; Rueness and Rueness 2000; Boudouresque and Verlaque 2002; Smith et al. 2002; Kim et al. 2004). The relocation of species causes confusion in seaweed biogeography. Natural or anthropogenic environmental derived changes have been reported in many species by several researchers (Thompson 1998; Mousseau et al. 2000; Umina et al. 2005). Oysters were one of the vectors that introduced many seaweeds from Japan into Europe in the past two centuries (Farnham 1994; Uwai et al. 2006a). Transoceanic introductions of marine organisms are an impact of the globalization of shipping systems. Fisheries have also been documented by a number of researchers in such introductions (Carlton and Hodder 1995; Ribera and Boudouresque 1995; Nelson et al. 1996; McIvor et al. 2001; Shaffelke et al. 2006; Uwai et al. 2006a). In Singaporean waters, introductions have been attributed to such vectors as aquaculture and shipping (Lee et al. 2009).

In conclusion, Morib was found to have the most divergent haplotypes of $G$. changii in this study. The $\mathrm{C} 1$ haplotype has been suggested as the common ancestor, with five haplotypes for $G$. changii along the west coast of Peninsular Malaysia. However, the genetic diversity $G$. changii cannot be clarified accurately due to the limited size of samples collected. Extensive sampling from a wider geographical area in Malaysia is essential to provide a better understanding of the genetic diversity of this potentially economically important agarophyte. The findings in the present study augmented our understanding of the genetic diversity of $G$. changii in this region and highlighted several interesting sampling locations for further investigation and will contribute significantly to ongoing studies. However, further conclusions can only be made with additional sampling of at least ten individuals from each location. The analysis on the genetic diversity of $G$. changii is ongoing with increased number of individuals from each location as well as from a wider geographical area.

Phylogeographic distribution analysis for marine algae with taxonomically doubtful fossil evidence is crucial to reveal their biogeographic and population histories (Vidal 2008) and requires an integration of morphological, molecular, and life history approaches (Zuccarello and West 2002). The mitochondrial marker cox 1 gene was shown to be suitable for resolving intraspecies relationships and is a reliable marker for the study of genetic variation in Gracilaria. However, it is essential to involve two or more sets of DNA-based molecular markers to resolve different depths of evolutionary relationships at the species level (Bellorin et al. 2002; Hayden et al. 2003) and to reveal cryptic diversity within $G$. changii in order to enhance the accuracy of resolution for the study of phylogeographic distribution.

Research on various aspects of $G$. changii including genetic transformation (Gan et al. 2003), tissue culture, proteomics (Wong et al. 2006), protoplast generation (Yeong et al. 2008), and functional genomes (Teo et al. 2007; Wong et al. 2007; Ho et al. 2009; Teo et al. 2009) have been carried out in Malaysia. There is no commercial cultivation of $G$. changii in Malaysia; however, the 
Department of Fisheries Malaysia carried out pond cultivation at Kuala Sungai Merbuk, Kedah (Phang 1998). Hence, large-scale cultivation of $G$. changii is essential for this economically important species. This study may provide insights into the origin and evolutionary relationships of $G$. changii in Malaysia and contribute to plant breeding programs for the most suitable strain or haplotype for cultivation. This study may also provide insights into the consequence of natural and anthropogenic impacts as well as evolutionary changes which have affected the distribution of $G$. changii. This information is important for the development of strategies for ex situ conservation of the ecologically important genetic resource of $G$. changii.

Acknowledgments This study was supported by Fundamental Research Grant Scheme (FRGS) Grant: Molecular Systematics of Gracilariales and Genetic Diversity of Gracilaria changii (FP 0442008A), University of Malaya Research Grant Scheme: Genetic Diversity of Gracilaria species (PS 136/2008A and PS 160/2009A), and Forest Research Institute Malaysia (FRIM) Grant: Checklist and Revision of Lower Plants of Malaysia (Marine Algae, no. 20300202030).

\section{References}

Avise JC (1994) Molecular markers, natural history and evolution. Chapman \& Hall, New York, 511 pp

Bellorin AM, Oliveira MC, Oliveira EC (2002) Phylogeny and systematics of the marine algal family Gracilariaceae (Gracilariales, Rhodophyta) based on SSU rDNA and ITS sequences of Atlantic and Pacific species. J Phycol 38:551-563

Bird CJ, Mclachlan J (1982) Some underutilized taxonomic criteria in Gracilaria (Rhodophyta, Gigartinales). Bot Mar 25:557-562

Boudouresque CF, Verlaque M (2002) Biological pollution in the Mediterranean Sea: invasive versus introduced macrophytes. Mar Pollut Bull 44:32-38

Brodie J, Zuccarello GC (2007) Systematics of the species-rich algae: red algal classification, phylogeny and speciation. In: Hodkinson TR, Parnell JAN (eds) Reconstructing the tree of life: taxonomy and systematic of species rich taxa. Systematics Association Special Volume Series 72. CRC, Boca Raton, pp 323-336

Buschmann AH, Correa JA, Westermeier R, Hernandez-Gonzalez MC, Norambuena R (2001) Red algal farming in Chile. Aquaculture 194:203-220

Byrne K, Zuccarello GC, West J, Liao ML, Kraft GT (2002) Gracilaria species (Gracilariaceae, Rhodophyta) from southeastern Australia, including a new species, Gracilaria perplexa sp. nov.: morphology, molecular relationships and agar content. Phycological Research 50:295-312

Carlton JT, Hodder J (1995) Biogeography and dispersal of coastal marine organism-experimental studies on replica of 16th century sailing vessel. Mar Biol 121:721-730

Cho GY, Kogame K, Kawaii H, Boo SM (2007) Genetic diversity of Scytosiphon lomentaria (Scytosiphonaceae, Phaeophyceae) from the Pacific and Europe based on RuBisCo large subunit and spacer, and ITS nrDNA sequences. Phycologia 46:657-665

Chu WL, Norazmi M, Phang SM (2003) Fatty acid composition of some Malaysian seaweeds. Malaysian Journal of Science 22:2127
Clement M, Posada D, Crandall KA (2000) TCS: a computer program to estimate gene genealogies. Mol Ecol 9:1657-1659

Coyer JA, Hoarau G, Stam WT, Olsen JL (2004) Geographically specific heteroplasmy of mitochondrial DNA in the seaweed, Fucus serratus (Heterokontophyta, Phaeophyceae, Fucales). Mol Ecol 13:1323-1326

Curiel D, Bellemo G, Marzocchi M, Scattolin M, Parisi G (1998) Distribution of the introduced Japanese macroalgae Undaria pinnatifida, Sargassum muticum (Phaeophyta) and Antithamnion pectinatum (Rhodophyta) in the Lagoon of Venice. Hydrobiologia 385:17-22

Farnham WF (1994) Introduction of marine benthic algae into Atlantic Europe waters. In: Boudouresque CF, Briad F, Nolan C (eds) Introduced species in European coastal waters. Europe Commission, Luxemburg, pp 32-36

Farnham WF, Fletcher RF, Irvine RL (1973) Atlantic Sargassum found in Britain. Nature 243:231-232

Fletcher RL, Farrell P (1999) Introduced brown algae in the north east Atlantic, with particular reference to Undaria pinnatifida (Harvey) Suringar. Helgoländer Meeresuntersuch 52:259-275

Gan SY, Qin S, Rofina YO, Yu D, Phang SM (2003) Transient expression of lacZ in particle bombarded Gracilaria changii (Gracilariaceae, Rhodophyta). J Appl Phycol 15:351-353

Geraldino PJL, Yang EC, Boo SM (2006) Morphology and molecular phylogeny of Hypnea flexicaulis (Gigatinales, Rhodophyta) from Korea. Algae 21:417-423

Gurgel CFD, Fredericq S (2004) Systematics of Gracilariaceae (Gracilariales, Rhodophyata): a critical assessment based on $r b c \mathrm{~L}$ sequence analyses. J Phycol 40:138-159

Hall TA (1999) BioEdit: a user-friendly biological sequence aligment editor and analysis program for Windows 95/98/NT. Nucleic Acids Symp Ser 41:95-98

Hayden HS, Blomster J, Maggs CA, Silva PC, Stanhope MJ, Waaland JR (2003) Linnaeus was right all along: Ulva and Enteromorpha are not distinct genera. Eur J Phycol 38:277-294

Ho CL, Teoh S, Teo SS, Raha AR, Phang SM (2009) Profiling the transcriptome of Gracilaria changii (Rhodophyta) in response to light deprivation. Mar Biotechnol 11:1436-2236

Hughes AR, Inouye BD, Johnson MTJ, Underwood N, Vellend M (2008) Ecological consequences of genetic diversity. Ecol Lett 11:609-623

Kim HS, Hwang IK, Lee WJ (2004) Evidence for taxonomic status of Pachydictyon coriaceum (Holmes) Okamura (Dictyotales, Phaeophyceae) based on morphology and plastid protein encoding $r b c \mathrm{~L}, p s a \mathrm{~A}$ and $p s b \mathrm{~A}$ gene sequences. Algae 19:175-190

Lee AC, Liao LM, Tan KS (2009) New records of marine algae on artificial structure and intertidal flats in coastal waters of Singapore. Raffles Bull Zool 22:5-40

Lim PE, Phang SM (2004) Gracilaria species (Gracilariales, Rhodophyta) of Malaysia including two new records. Malays J Sci 23:71-80

Marston M, Villalard-Bohnsack M (2002) Genetic variability and potential sources of Grateloupis doryphora (Halymeniaceae, Rhodophyta), an invasive species in Rhode Island waters (USA). J Phycol 38:649-658

McIvor L, Maggs CA, Provan J, Stanhope MJ (2001) $r b c L$ sequences reveal multiple cryptic introductions of the Japanese red alga Polysiphonia harveyi. Mol Ecol 10:911-919

McLachlan J, Bird CJ (1986) Gracilaria (Gigartinales, Rhodophyta) and productivity. Aquat Bot 26:27-49

Mousseau TA, Sinervo B, Endler JA (2000) Adaptive genetic variation in the wild. Oxford University Press, New York

Nam KW, Maggs CA, McIvor L, Stanhope MJ (2000) Taxonomy and phylogeny of Osmunder (Rhodomelaceae, Rhodophyta) in Atlantic. Eur J Phycol 36:759-772

Nelson WA, Maggs CA, McIvor L, Stanhope MJ (1996) Records of adventives marine algae in New Zealand: Antithamnionella 
ternifolia, Polysiphonia senticulosa (Ceramiales, Rhodophyta) and Striaria attenuate (Dictyosiphonales, Phaeophyta). NZ J Mar Freshw Res 30:449-453

Oliveira EC, Alveal IK, Anderson R (2000) Mariculture of the agarproducing Gracilarioid red algae. Rev Fish Sci 8:345-377

Phang SM (1994) Some species of Gracilaria from Peninsular Malaysia and Singapore. In: Abbott IA (ed) Taxonomy of economic seaweeds with reference to some Pacific and Caribbean species, vol V. California Sea Grant College Publication, La Jolla, pp 125-134

Phang SM (1998) The seaweed resources of Malaysia. In: Critchley AT, Ohno M, Largo DB, Gillespie RD (eds) Seaweed resources of the world. Japan International Cooperation Agency, Yokosuka, pp 79-91

Phang SM, Shaharuddin S, Noraishah H, Sasekumar A (1996) Studies on Gracilaria changii (Gracilariales, Rhodophyta) from Malaysian mangroves. Hydrobiologia 326/327:347-352

Ribera MA, Boudouresque CF (1995) Introduced marine plants, with special reference to macroalgae, mechanisms and impact. Prog Phycol Res 11:187-268

Robba L, Russell SJ, Barker GL, Brodie J (2006) Assessing the use of mitochondrial cox 1 marker for use in DNA barcoding of red algae (Rhodophyta). Am J Bot 93:1101-1108

Rueness J (1989) Sargassum muticum and other introduced Japanese macroalgae: biological pollution of European coasts. Mar Pollut Bull 20:173-176

Rueness J (2005) Life history and molecular sequences of Gracilaria vermiculophylla (Gracilariales, Rhodophyta), a new introduction of European waters. Phycology 44:120-128

Rueness J, Rueness EK (2000) Caulacanthus ustulatus (Gigartinales, Rhodophyta) from Brittany (France) is an introduction from the Pacific Ocean. Cryptogamie Algologie 21:355-363

Saunders GW (2005) Applying DNA barcoding to red macroalgae: a preliminary appraisal holds promise for future applications. Philos Trans R Soc 360:1879-1888

Shaffelke B, Smith JE, Hewitt CL (2006) Introduced macroalgae-a growing concern. J Appl Phycol 18:529-541

Sherwood AR (2008) Phylogeography of Asparagopsis taxiformis (Bonnemaisoniales, Rhodophyta) in the Hawaiian Islands: two mtDNA markers support three separate introductions. Phycologia 47:79-88

Smith JE, Hunter CL, Smith CM (2002) Distribution and reproductive characteristics of nonindigenous and invasive marine algae in the Hawaiian Islands. Pac Sci 56:299-315

Steel DJ, Trewick SA, Wallis GP (2000) Heteroplasmy of mitochondrial DNA in the ophiuroid Asterobrachion constricum. J Hered 91:146-149

Swofford DL (2002) PAUP*. Phylogenetic analysis using parsimony (* and other methods), version 4. Sinauer, Sunderland

Teo SS, Ho CL, Teoh S, Lee WW, Tee JM, Raha Abd Rahim, Phang SM (2007) Analyses of expressed sequence tags from an agarophyte, Gracilariales, Rhodophyta. Eur J Phycol 42:41-46

Teo SS, Ho CL, Teoh S, Raha Abd Rahim, Ohang SM (2009) Transcriptomic analysis of Gracilaria changii (Rhodophyta) in response to hyper- and hypoosmotic stresses. J Phycol 45:10931099

Thompson JN (1998) Rapid evolution as an ecological process. Trend Ecol Evol 13:329-332

Thompson JD, Gibson TJ, Plewniak F, Jeanmougin F, Higgins DG (1997) The Clustal X windows interface: flexible stratrgies for multiple sequence alignment aided by quality analysis tools. Nucleic Acids Res 24:4876-4882

Umina PA, Weeks AR, Kearney MR, McKechnie SW, Hoffmann AA (2005) A rapid shift in a classic clinal pattern in Drosophila reflecting climate change. Science 308:691-693

Uwai S, Nelson W, Neill K, Wang WD, Aguilar-Ross LE, Boo SM, Kitayama T, Kawaii H (2006a) Genetic diversity in Undaria pinnatifida (Laminariales, Phaeophyceae) deduced from mitochondria genes - origin and succession of introduced populations. Phycologia 45:687-695

Uwai S, Yotsukura N, Serisawa Y, Muraoka D, Hiraoka M, Kogame K (2006b) Intraspecific genetic diversity of Undaria pinnatifida in Japan, based on the mitochondrial of cox3 gene and ITS1 of nrDNA. Hydrobiologia 553:345-356

Vidal R (2008) Phylogeography of the genus Spongites (Corallinales, Rhodophyta) from Chile. J Phycol 44:173-182

Wong PF, Tan LJ, Nawi H, AbuBakar S (2006) Proteomics of the red alga, Gracilaria changii (Gracilariales, Rhodophyta). J Phycol 42:113-120

Wong TK-M, Ho CL, Lee WW, Raha Abd Rahim, Phang SM (2007) Analyses of expressed sequence tags from Sargassum binder (Phaeophyta). J Phycol 43:528-534

Xia BM, Abbott IA (1987) New species of Polycarvernosa Chang and Xia (Gracilariaceae, Rhodophyta) from the western Pacific. Phycologia 26:405-418

Yang EC, Kim MS, Geraldino PJL, Sahoo D, Shin JA, Boo SM (2007) Mitochondrial cox 1 and plastid $r b c \mathrm{~L}$ genes of Gracilaria vermiculophylla (Gracilariaceae, Rhodophyta). J Appl Phycol 20:161-168

Yeong HY, Khalid N, Phang SM (2008) Protoplast isolation and regeneration from Gracilaria changii (Gracilariales, Rhodophyta). J Appl Phycol 20:641-651

Zuccarello GC, West JA (2002) Phylogeography of the Bostrychia calliptera-B. pinnata complex (Rhodomelaceae, Rhodophyta) and divergence rates based on nuclear, mitochondrial and plastid DNA markers. Phycologia 41:49-60

Zuccarello GC, Burger G, West JA, King RJ (1999) A mitochondrial marker for red algal intraspecific relationships. Mol Ecol 8:14431447

Zuccarello GC, Buchnan J, West JA (2006a) Increased sampling for inferring phylogeographic patterns in Bostrychia radicans/ B. moritziana (Rhodomelaceae, Rhodophyta) in the eastern USA. J Phycol 42:1349-1352

Zuccarello GC, Critchley AT, Smith J, Sieber V, Lhonneur GB, West JA (2006b) Systematics and genetic variation in commercial Kappaphycus and Eucheuma (Solieriaceae, Rhodophyta). J Appl Phycol 18:643-651 